\title{
TAX TREATMENT OF LUMP-SUM DISTRIBUTIONS FROM PREVIOUSLY QUALIFIED EMPLOYEE PENSION PLANS
}

Most corporations compensate their employees through employee benefits as well as basic wages and salaries. ${ }^{1}$ One such benefit, the pension plan, ${ }^{2}$ is designed to prepare the employee for the reduction or loss of income that attends retirement. The employer contributes pre-tax funds in the name of the employee, and the employee can usually supplement that amount through direct contributions of his own. For federal tax purposes, these private pension plans are classified as either qualified or nonqualified. ${ }^{3}$

Contributions to a qualified tax-exempt pension fund benefit both the employer and the employee. The employer contributions are deductible within the limits set forth in sections 404(a)(1)-(3) of the Internal Revenue Code (the Code). The employee can defer income taxes on

1. As of December 1985 , the total dollars invested in private pension plans had reached $\$ 1.4$ trillion. The vast majority of these funds were invested in qualified, rather than nonqualified plans. Telephone interview with the Office of Policy and Research, U.S. Department of Labor (Feb. 4, 1986).

2. As used in this note, "pension plan" means a program or fund established by an employer for the benefit of his eligible employees, or their beneficiaries, over a period of years after retirement. Examples include profit-sharing, stock-bonus, and defined-benefit plans. This note does not specifically address Keogh plans, individual retirement accounts, or annuities.

3. Whether an employee is a participant in a qualified plan is governed by the interaction of three sections of the Internal Revenue Code. Section 401 sets out the required vesting, coverage, and funding levels. Unless these requirements are met, the plan is considered nonqualified.

The taxability of the benefits from a qualified pension plan is set out in section 402(a):

[T] he amount actually distributed .... [from a trust] described in section 401(a) which is exempt from tax under section 501 (a) shall be taxable ... in the year in which so distributed.

I.R.C. $\S 402(a)(1)$ (1982). The section then describes the preferential methods of taxing a lump-sum distribution, including capital gains treatment, forward averaging, and rollover treatment.

The tax treatment for a distribution from a nonqualified pension plan is set out in section 402(b):

Contributions to an employees' trust made by an employer during a taxable year of the employer which ends within or with a taxable year of the trust for which the trust is not exempt from tax under section 501(a) shall be included in the gross income of the employee .... The amount actually distributed or made available to any distributee by any such trust shall be taxable . . . in the year in which so distributed or made available ....

Id. $\S 401$ (b) (emphasis added). The main qualification requirements under section 401(a) are that the plan be for the exclusive benefit of employees or their beneficiaries, id. $\S 401(\mathrm{a})(2)$, and that it does not discriminate in favor of highly compensated employees. Id. $\S 401(a)(4)$.

These provisions were not substantially modified by the Tax Reform Act of 1986, Pub. L. No. 99-514, 100 Stat. 2085. 
those funds contributed until distribution and, usually, can contribute additional funds up to a certain percentage. These two features allow tax-exempt accumulation of the employee's funds in preparation for retireinent. ${ }^{4}$ When the employee pays taxes on the funds received, he can choose (1) capital-gains treatment for any portion of the funds contributed before $1974,{ }^{5}$ (2) five-year forward averaging for funds contributed after $1974,{ }^{6}$ or (3) rollover of the funds into another qualifying pension fund or an IRA. ${ }^{7}$

The employee has these tax options at retirement if the company's pension fund has remained qualified. Federal courts are split, however, over whether the options should be available if the einployer's fund has become disqualified. The United States Court of Appeals for the Second Circuit and the Tax Court have allowed preferential tax treatment for funds contributed before the disqualification date. The United States Courts of Appeals for the Fifth, Sixth, and Seventh Circuits have rejected this approach. Instead, these courts tie the tax treatment to the date of distribution. Snice all funds will necessarily be distributed only after the disqualification date, preferential tax treatment is wholly denied under this approach.

Typically, pension plans are disqualified retroactively for failing to meet coverage or contribution requirenients. New top-heavy plan rules introduced by Tax Equity and Fiscal Responsibility Act of 1982 and by

4. The advantages to the employee of accumulating retirement funds on a tax-free basis are significant. If, for example,

an employee was age thirty when he entered the plan and employer contributions were made at $\$ 2,000$ per year and grew at a $12 \%$ rate of return, then the total benefit would be $\$ 996,926$ at age sixty-five. However, if the employee received his salary (which would be taxed) and then invested $\$ 2,000$ per year at the same $12 \%$ rate in a regular savings account, then the total after tax benefit would be $\$ 118,121$. Increase the rate of return and yearly contributions and the difference between taxed and tax-free growth will become even more remarkable.

Comment, How to Accomplish a Successful Tax-Free Pension Plan Rollover, 8 PEPPERdine L. REv. 933, 937 n.26 (1981).

5. This option is available, on an increasingly limited basis, through 1991. The Tax Reform Act of 1986 established special transition rules phasing out capital gains treatment over a five-year period beginning January 1,1987 . This is accomplished by applying a phase-out percentagc to the amount that would have been treated as long-term capital gains under prior law. See I.R.C. $\S 402$ (a)(2), (e)(4) (1982 \& Supp. III 1985), as amended by Tax Reform Act of 1986, Pub. L. No. 99514, § 1122(b)(1), (h)(4), 100 Stat. 2085, 2466, 2471.

Individuals who have attained age 50 before January 1, 1986 are allowed under the transition rules to elect capital gains treatment with respect to a lump-sum distribution, without regard to the five-year phase-out plan. The pre-1974 portion of the distribution will be taxed at a rate of 20 percent. I.R.C. § 402(a)(2), (e)(4) (1982), as amended by Tax Reform Act of 1986, Pub. L. No. 99. 514, § 1122(b)(1), (h)(3); 100 Stat. 2085, 2466, 2470-71.

6. Individuals who are $591 / 2$ or older may elect to use five-year forward averaging with regard to a single lump sum received. I.R.C. $\S 402(\mathrm{e})(1)(\mathrm{c})(1982)$, as amended by Tax Reform Act of 1986, Pub. L. No. 99-514, § 1122(a)(2), 100 Stat. 2085, 2466.

7. I.R.C. $\S 402(\mathrm{a})(5)(1982)$. 
the Tax Reform Act of 1986 threaten to cause an increase in the number of plan disqualifications. ${ }^{8}$ With potentially more disqualifications, the tax treatment of lump-sum distributions from previously qualified employee pension plans could affect a greater range of taxpayers.

This note discusses the controversies surrounding this tax treatment. First, it discusses the tax legislation governing employee pension plans, with special attention to the taxation of lump-sum distributions. ${ }^{9}$ It then examines the conflicting judicial approaches to resolving the issue of distribution taxation. ${ }^{10}$ Finally, it analyzes the courts' interpretations of sections 402(a) and 402(b), the legislative history of those sections, and relevant equitable considerations. ${ }^{11}$ The note concludes that the Code and apphicable Treasury regulations require the demial of preferential tax treatment for any distribution made after the plan is disqualified, despite the possible inequities that may be worked on the individual employee.

\section{Employee Pension Plans and the Code}

\section{A. Tax Treatment of Lump-Sum Distributions from Employee Pension Plans.}

Since the colonial period, Americans have attempted to retain funds during their most productive years in preparation for the time when they would be too old or infirm to support themselves. ${ }^{12}$ In modern times, employers have aided employees in this effort by establishing einployee pension funds. The early pension plans were largely unregulated. In 1926, however, the federal government sought to encourage the growth of private pension plans by legislating favorable tax treatment for the distributions of private pension plans. The 1926 Act allowed einployees to defer taxation on contributions to a pension trust until the funds were distributed back to them, usually at retirement. ${ }^{13}$ Since 1926 , Congress has made piecemeal modifications to the laws governing pension fund distributions. ${ }^{14}$

8. Musick, TC Allows Partial Favorable Treatment on Distributions from Formerly Qualified Plans, 62 J. TAX'N 134, 134 (1985).

9. See infra notes $12-32$ and accompanying text.

10. See infra notes $33-71$ and accompanying text.

11. See infra notes $72-92$ and accompanying text.

12. See B. Franklin, Poor Richard's Almanac (1754) ("For Age and Want save while you may; No morning Sun lasts a whole Day.").

13. Revenue Act of 1926, ch. 27, § 219(f), 44 Stat. 9, 33-34.

14. The Revenue Act of 1928 was the first to make employer contributions to a fund deductible. Revenue Act of 1928, ch. 852, § 23(q), 45 Stat. 791, 802. The Revenue Act of 1938 more strictly defined the requirements for establishing and operating an exempt trust. Revenue Act of 1938, ch. 289, § 165(a), 52 Stat. 447, 518.

In the Revenue Act of 1942, Congress redefined these requirements, Revenue Act of 1942, ch. $619, \S 162(a), 56$ Stat. $798,862-63$, revised the rules regarding deductibility of contributions, $i d$. 
The term "Iump-sum distribution" was first introduced in section 162(a) of the Revenue Act of 1942. The 1942 Act conferred capital gains

$\S 162(b), 56$ Stat. at $863-66$, and provided for capital gains trcatment of distributions for the first time. Id. $\S 162$ (a), 56 Stat. at 863 . Although the House saw a need for extensive revision of the rules governing employee trusts prior to the passage of the Internal Revenue Code of 1954, H.R. REP. No. 1337, 83d Cong., 2d Sess. $42-46$ (1954), the Senate refused to adopt any sweeping changes and adhered to the pattern established in previous legislation. S. REP. No. 1622, 83d Cong., 2d Sess. 5354 (1954).

The Tax Reforn Act of 1969 amended the Internal Revenue Code of 1954 and included a provision to limit the capital gains treatment of certain types of plan distributions. Tax Reform Act of 1969, Pub. L. No. 91-172, § 515(a), 83 Stat. 487, 643-44.

Not until 1974, with the passage of the Employee Retirement Income Security Act (ERISA), Pub. L. No. 93-406, 88 Stat. 829 (1974), did Congress make a comprehensive effort to remedy the madequacies in pension coverage, vesting, and funding. ERISA's breadth necessitated the revision of most existing pension plans.

ERISA provided specific definitions for employee benefit plans, and divided employee pension plans into two categories: (a) defined benefit plans (plans that specify the benefit to the employee), ERISA $\S 1015$, I.R.C. $\S 414(j)$ (1982); and (b) defined contribution plans (plans that specify the contribution by the employer). ERISA § 1015, I.R.C. $\S 414$ (i) (1982).

ERISA also established detailed qualification requirements for tax-exempt pension trusts. There are three kinds of minimum qualification standards:

(1) Plan participation requirements. These speeify the length of time an employer can require an employee to wait before becoming a participant in the pension or profit-sharing plan. I.R.C. $\S 410$ (a)(1) (West Supp. 1986); id. § 414(a) (1982). Additionally, the plan cannot discriminate in favor of officers, shareholders, or higlily compensated employees in the allocation of benefits to be received or contributions to be made. Id. $\S 401$ (a)(4) (West Supp. 1986); id. § 410(b)(1)(B) (1982). (2) Vesting requirements. These specify the length of time an employee must wait before acquiring a nonforfeitable interest in the plan. Id. $\$ 411$ (West Supp. 1986). For example, an employee must be at least $50 \%$ vested at the end of ten years of service under all three of the vesting schedules set out in the Code. Id. $\S 411$ (a)(2) (1982).

(3) Contribution requirements. These specify the minimum contributions an employer must make to the plan. Id. $\S 412$ (West Supp. 1986). Generally, the yearly contribution to a qualified pension plan must be sufficient to cover the amounts that will be payable upon employee retirement. Id.

For a more detailed discussion of the qualification requirements established by ERISA, sce Comment, supra note 4, at 935 n.13.

Since ERISA was enacted, Congress has made almost yearly adjustments to pension plan legislation. Three recent modifications were the Tax Equity and Fiscal Responsibility Act of 1982, Pub. L. No. 97-248, 96 Stat. 324, the Deficit Reduction Act of 1984, Pub. L. No. 98-369, 98 Stat. 494, and the Tax Reform Act of 1986, Pub. L. No. 99-514, 100 Stat. 2085. The Tax Equity and Fiscal Responsibility Act sought to equalize the tax treatment of pensions of self-employed persons by bringing Keogh Plan treatment in line with that of corporate plans. See Stokes \& Rasmussen, Direct Transfer of Assets Between Plans Often More Advantageous than IRA Rollover, 33 TAX'N FOR ACCT. 374, 377 (1984). It also introduced the provisions applicable to top-heavy pension plans, i.e., tlose that benefit primarily key personnel. See Laibstain \& Lander, Benefits, Contributions, and Distributions of Qualified Plans All Affected by the New Law, 33 TAx'N FOR ACCT. 76, 76-77 (1984). The Deficit Reduction Act altered the treatment of distributions made prior to the time the recipient reaches $591 / 2$, rollovers of partial distributions, spousal rollovers and seetion 403(b) plan rollovers. See Sollee \& Stone, New Law Brings Major Changes Affecting Pre-59 1/2 Distributions and Rollovers, 61 J. TAX'N 130, 130-33 (1984). The Tax Reform Act again altered the rules regarding discriminatory coverage and highly compensated employees, and provided new minimum vesting sehedules. It also altered the treatment of distributions from qualified plans and changed the limits on cmployer deductions for contributions to qualified plans. Tax Reform Act of 1986, Pub. L. No. 99-514, 100 Stat. 2085. 
treatment on all lump-sum distributions defined as "total distributions ... paid to the distributee within one taxable year," if made "on account of the employee's separation from the service."1s Today, the Code defines a lump-sum distribution as the payment or distribution, within one taxable year, of an employee's credit balance with a qualified plan, ${ }^{16}$ made (a) on account of the employee's death, ${ }^{17}$ (b) after the employee attains age $591 / 2,18$ (c) on account of the employee's separation from the service, ${ }^{19}$ or (d) after the participant has become disabled. ${ }^{20}$

Upon receipt, a distribution may be taxed in one of three ways: ${ }^{21}$ the capital gains method for all pre-1974 contributions, 22 five-year forward averaging of the post- 1974 contributions, ${ }^{23}$ or rollover of the distribution into another qualified pension fund or into an IRA. ${ }^{24}$ The appropriate choice depends not only on the date of contribution (pre-1974 or post1974), but also on a host of other factors, including how close the employee is to retirement and how much other income the employee expects

For a more detailed presentation of the development of employee pension plan legislation, see 6 M. Weinstein, Mertens LAw of Federal InCOME TAXation $§ 25 B .02$ (1985).

15. Revenue Act of 1942 , ch. $619, \S 162$ (a), 56 Stat. $798,863$.

16. The main qualification requirements of a qualified plan are that it be for the exclusive benefit of the employees or their beneficiaries, and that it does not discriminate in favor of officers, shareholders, or highly compensated employees. For a discussion of the test the IRS uses in determining whether a plan is nondiscriminatory, see Stuart, How to Prevent Disqualification of a Plan for Failure to Meet the Coverage Test, 27 TAX'N For ACCT. 240 (1981).

17. I.R.C. $\$ 402(\mathrm{e})(4)(\mathrm{A})(\mathrm{i})$ (West Supp. 1986).

18. Id. $\S 402(\mathrm{e})(4)(\mathrm{A})(\mathrm{ii})$.

19. Id. $\S 402(\mathrm{e})(4)(\mathrm{A})(\mathrm{iii})$. For a discussion of the meaning of "separation from service," see United States v. Johnson, 331 F.2d 943, 945-54 (5th Cir. 1964); Hessenthaler \& Lohwater, Lumpsum Distributions: Determining When "Separation from Service" Occurs, 10 TAX'N FOR LAw. 272, 272-78 (1982).

20. I.R.C. $\S 402$ (e)(4)(A)(iv) (1982). An individual is disabled if "he is unable to engage in any substantial gainful activity by reason of any medically determinable physical or mental impairment which can be expected to result in death or to be of long-continued and indefinite duration." Id. $\S 72(\mathrm{~m})(7)$.

21. See infra notes 22-24 and accompanying text. In some instances, a combination of these methods may be used; partial distributions may also qualify. 5 Fed. Taxes (P-H) \{I 19,196, 19,201 (1987).

22. I.R.C. \$ 402(a)(2), (e)(4) (1982 \& Supp. III 1985). However, the Tax Reform Act of 1986, Pub. L. No. 99-514, § 1122(b)(1), (h)(4), 100 Stat. 2085, 2466, 2471, phases out capital gains treatment over five years beginning January 1, 1987.

23. I.R.C. $\$ 402(\mathrm{e})(1)(\mathrm{C})(1982)$, as amended by Tax Reform Act of 1986, Pub. L. No. 99-514, $\S 1122(\mathrm{e})(2), 100$ Stat. 2085, 2466.

24. I.R.C. $\$ \S 402(a)(5)(A), 408(d)(3)(A)$, (B) (1982 \& Supp. III 1985). The IRA alternative has two major disadvantages: (1) distributions from an IRA are taxed as ordinary income, and (2) a $10 \%$ penalty is generally imposed if funds are withdrawn early. See Comment, supra note 4, at 943 n.69.

The Tax Reform Act of 1986, Pub. L. No. 99-514, § 1122(e)(1), 100 Stat. 2085, 2469, also provides that partial distributions may be rolled over only if the distribution is made on account of the death of the employee, on account of the employee's separation from service, or after the employee has been disabled. 
to receive that tax year and in retirement. In choosing the method of taxation, the employee generally will seek to maximize after-tax cash flow during retirement. ${ }^{25}$

\section{B. Pension Plan Disqualification.}

Disqualification of a pension plan occurs when the IRS determines that the plan does not meet the necessary requirements for exempt status. The defect can be either in the form or in the operation of the plan. In rectifying defects in the pension's form, i.e., its provisions, ample opportumity is available for amending the plan. ${ }^{26}$ Generally speaking, section 401(b) and its regulations provide greater latitude for retroactive amendment to the form of a plan than was permitted prior to ERISA. ${ }^{27}$

It is inore frequently the operation of a pension plan that causes disqualification. ${ }^{28}$ When disqualification does occur because of a violation of this kind, the disqualification is often retroactive, i.e., the plan is considered disqualified as of the date of the violation, not the date of the adjudication. ${ }^{29}$ In such case, the loss of all preferential tax treatment is

25. For discussions of the factors that should be weighed when making the choice, see Esterces, Ten-year Averaging Election for Lump-sum Distributions Not Always the Best Approach, 9 TAX'N FOR LAw. 272 (1981); Hoyt, Choosing Between Special Ten-year Averaging and Deferring Tax Through a Rollover, 60 J. TAX'N 90 (1984); Stokes \& Rasmussen, Direct Transfer of Assets Between Plans Often More Advantageous Than IRA Rollover, 33 TAx'N FOR ACCT. 374 (1984).

26. I.R.C. $\S 401$ (b) (1982) provides:

A stock bonus, pension, profit-sharing, or annuity plan shall be considered as satisfying the requirements of subsection (a) for the period beginning with the date on which it was put into effect, or for the period beginning with the earlier of the date on which there was adopted or put into effect any amendment which caused the plan to fail to satisfy such requirements, and ending with the time prescribed by law for filing the return of the employer for his taxable year in which such plan or amendment was adopted (including extensions thereof) or such later time as the Secretary may designate, if all provisions of the plan which are necessary to satisfy such requirements are in effect by the end of such period and Id. have been made effective for all purposes for the whole of such period.

27. See Stogel \& Ervin, Keeping the Qualified Pension Plan Qualified and Recognizing the Tax Effects of Disqualification, 1977 WASH. U.L.Q. 565, $567-70$ (describing disqualification process before and after ERISA).

28. Not every violation results in disqualification; ERISA imposes excise taxes for less grievous violations. Under ERISA, specific excise tax penalties are tied to certain prohibited transactions. I.R.C. $\S 4975(a)$, (c) (1982). The Tax Reform Act of 1986, Pub. L. No. 99-514, § 1121(a)(1), 100 Stat. 2085, 2464, imposes an excise tax for another transgression that had previously triggercd plan disqualification: failure to satisfy minimum distribution requirements.

29. See, e.g., Benbow v. Commissioner, 774 F.2d 740 (7th Cir. 1985).

The Commissioner has considerable discretion in applying decisions retroactively. See I.R.C. $\S 7805$ (b) (1982). A court must uphold a retroactive application unless the application constitutes an abuse of discretion. See Boggs v. Commissioner, 784 F.2d 1166, 1169 (4th Cir. 1986); see also Automobile Club v. Commissioner, 353 U.S. 180, 184-85 (1957) (similarly interpreting the predecessor of section 7805(b)).

The Commissioner's discretion has been circumscribed to some extent, however. The Statement of Procedural Rules, 26 C.F.R. $\S 601.201(l)(5)$ (1986), provides: 
particularly burdensome for the employee. ${ }^{30}$ Once an adverse ruling has been made by the IRS and the employee has exhausted his administrative remedies, the employee's only option is to seek a declaratory judgment that the plan is qualified ${ }^{31}$ or bring a suit for refund. ${ }^{32}$

\section{The Conflicting INTERPRetations of Section 402(a)(2)}

It is in the midst of ever-continuing congressional action that the courts have had to wrestle with appeals from employees whose pension trusts have been disqualified. These appeals center around the issue of whether section 402(a)(2) confers preferential treatment upon employer contributions made to a qualified trust if the trust's qualified status is later revoked.

In Greenwald v. Commissioner, ${ }^{33}$ the United States Court of Appeals for the Second Circuit held that pension funds contributed prior to disqualification should receive preferential treatment. Subsequent district court and Tax Court decisions ${ }^{34}$ followed the Greenwald holding. How-

Except in rare or unusual circumstances, the revocation or modification of a ruling will not be applied retroactively with respect to the taxpayer to whom the ruling was originally issued or to a taxpayer whose tax liability was directly involved in such ruling if (i) there has been no misstatement or omission of material facts, (ii) the facts subsequently developed are not materially different from the facts on which the ruling was based, (iii) there has been no cliange in the apphicable law, (iv) the ruling was originally issued with respect to a prospective or proposed transaction, and (v) the taxpayer directly involved in the ruling acted in good faith in reliance upon the ruling and the retroactive revocation would be to his detriment.

The Commissioner is required to abide by 26 C.F.R. $\$ 601.201(l)(5)$ because it is "reasonably based on" I.R.C. § 7805(b). Lansons, Inc. v. Commissioner, 622 F.2d 774, 776-77 (4th Cir. 1980).

For additional information on retroactivity and revocations, see Knox, Retroactive Qualification, Disqualification of Employee Retirement Plans, 61 J. TAX'N 84 (1984); Comment, Limits on Retroactive Decision Making by the Internal Revenue Service: Redefining Abuse of Discretion Under Section 7805(b), 23 UCLA L. REV. 529 (1970).

30. If the employee is not fully vested upon disqnalification and his vested interest subsequently increases, he must include in his income for the taxable year the change in the value of his share of the trust assets (less any liabilities, including taxes). Treas. Reg. $\S 1.402(b)-1(b)(2)$ (1978). If contributions are made over time after the plan is disqualified, the employee must report as income the portion of the contributions made during the taxable year that are vested in addition to the increase of the value of his vested interest. Treas. Reg. $\S 1.402$ (b)-1(a), (b)(4) (1978).

If the disqualification is retroactive, the employee would also be required to pay interest on any additional taxes. As one commentator notes:

Disqualification of a plan alters its function; rather than being a "fringe benefit," it almost immediately becomes a detriment, because the employee must pay income taxes with his own aftertax dollars without receiving any fnnds from the plan. In addition, the employee's tax return will be subjected to at least a cursory IRS audit.

Stogel \& Ervin, supra note 27, at 589 n.119.

31. I.R.C. $\$ 7476(1982)$

32. I.R.C. $\$ 7422$ (1982).

33. 366 F.2d 538, 541 (2d Cir. 1966).

34. See Hesse v. United States, 81-1 U.S. Tax Cas. (CCH) I 9153, at 86,212 (E.D. Mo. 1980); Dudinsky v. United States, 78-2 U.S. Tax Cas. (CCH) I 9688, at 85,300 (M.D. Fla. 1978); Pitt v. United States, 75-1 U.S. Tax Cas. (CCH) ๆ 9472, at 87,245 (M.D. Fla. 1975); Sturdivant v. Commis- 
ever, in Woodson v. Commissioner, ${ }^{35}$ the United States Court of Appeals for the Fifth Circuit rejected the Greenwald approach and held that funds distributed froin a disqualified trust were not entitled to favorable tax treatment, even if contributed while the pension fund was tax-exempt. In essence, the Fifth Circuit tied the availability of preferential tax treatment to the time of fund distribution, rather than contribution. 36 The United States Courts of Appeals for the Sixth ${ }^{37}$ and Seventh ${ }^{38}$ Circuits have agreed with the Woodson approach. A thorough analysis of the mdividual cases is necessary to understand the parameters of the conflict.

\section{A. Greenwald v. Commissioner.}

Greenwald was an officer of Interstate Hosiery Mills, Inc., a publicly held corporation. Interstate provided employees with a profit-sharing trust, and Greenwald was a participant. In 1953, Interstate was sold to Burlington Mills Corporation. Upon coinpletion of the sale, fifty-nine of the sixty employees participating in the profit-sharing trust received distributions due to their separation from service. Only Greenwald reinained as a participant. No additional einployer contributions were made to the trust until 1959, when the trust entered into a reorganization agreement with Fundamental Investors, Inc. The reorganization agreeinent called for an exchange of the trust's assets for Fundamental stock. The stock acquired by the trust was then distributed in full to Greenwald in 1959.39

The IRS contended, and the Tax Court held, that the trust ceased to be tax-exempt im 1953.40 The Tax Court concluded that no part of the eventual distribution to Greenwald was eligible for preferential tax treatment under section 402(a)(2) because the trust was not tax-exempt at the time of distribution. ${ }^{41}$

On appeal, the Second Circuit agreed that the trust lost its tax ex-

sioner, 39 T.C.M. (CCH) 1022, 1025 (1980); Woodson v. Commissioner, 73 T.C. 779, 786 (1980), rev'd, 651 F.2d 1094 (5th Cir. Unit A July 1981).

35. 651 F.2d 1094, 1095-96 \& n.3 (5th Cir. Unit A July 1981).

36. Id. at 1096 .

37. Baetens v. Commissioner, 777 F.2d 1160, 1163-67 (6th Cir. 1985).

38. Benbow v. Commissioner, 774 F.2d 740, 743-45 (7th Cir. 1985).

39. Greenwald, 366 F.2d at 539-40.

40. Greenwald v. Commissioner, 44 T.C. 137, 148-49 (1965). The Tax Court held that the plan was disqualified because it discriminated in favor of Greenwald, contrary to the standards set out in section 401(a)(4), and because employer contributions ceased to be "recurring and substantial." Id. at 149.

41. Greenwald, 44 T.C. at 149. 
empt status in $1953 .{ }^{42}$ However, it disagreed with the Tax Court's holding that loss of tax-exempt status by the trust should result in the complete denial of preferential tax treatment for the distribution. ${ }^{43}$ The Second Circuit advocated bifurcation of the trust into exempt and nonexempt portions. The distributions of each portion would be treated separately, with the exempt distributions governed by section 402(a)(2) and the nonexempt distributions governed by section 402(b). ${ }^{44}$

The court contended that this tax treatment was supported by the year-by-year consideration of exempt status mentioned in the Code. ${ }^{45}$ Furthermore, the court found that section 402(a) did not directly address the tax position of a previously qualified trust. In liglit of this perceived anibiguity, the court concluded that it should afford the employee the optimal tax position allowable. Finally, the court noted that bifurcation of the trust was consistent with congressional intent "simce it affords capital ganis treatment only so long as a ... trust remains nondiscriminatory in operation." 46 This bifurcation would result in tax treatment of the exempt portion of the distribution in parity with the tax treatment received by the other employees upon separation from service. ${ }^{47}$ For these reasons, the court concluded that preferential tax treatment should be available for those funds distributed from the portion of the trust representing the pre-1953 contributions. ${ }^{48}$

42. Greenwald, 366 F.2d at 540 . The court found the discriminatory nature of the trust to be conclusive and did not consider other grounds for disqualification. Id. at 540-41.

43. Id. at 541 .

44. Id.

45. Id. See I.R.C. $\$ 402(b)$ (1982) (contributions includable in employee's gross income if made during a taxable year of the employer ending "within or with a taxable year of the trust for which the trust is not exempt from tax").

46. Greenwald, 366 F.2d at 541.

47. Id.

48. Id. Following Greenwald, but before the Fifth Circuit decided Woodson, three district court cases addressed this issue. See Dudinsky v. United States, 78-2 U.S. Tax Cas. (CCH) I 9688, at 85,300 (M.D. Fla. 1978); Pitt v. United States, 75-1 U.S. Tax Cas. (CCH) \ 9472, at 87,245 (M.D. Fla. 1975); Hesse v. United States, 81-1 U.S. Tax Cas. (CCH) ๆ 9153, at 86,211-12 (E.D. Mo. 1980).

These cases-Pitt, Dudinsky, and Hesse-were all decided after the enactment of ERISA in 1974. Yet in none of these cases did the district court reexamine the Code in light of the new legislation. Rather, the courts strictly, and in cursory fashion, adhered to the Second Circuit's ruling in Greenwald. In the only case to bring new arguments to bear, Hesse, the holding focused on equitable considerations rather than statutory interpretation or ERISA's statutory scheme. The court emphasized the lack of control exercised by the employee over the trust. Hesse, 81-1 U.S. Tax Cas. (CCH) at $86,211-12$. The court found it unfair to "retroactively change the ground rules" on which the employee had relied in planning for retirement. Id. at 85,212 (quoting Woodson v. Commissioner, 73 T.C. 779, 784 (1980), rev'd, 651 F.2d 1094 (5th Cir. Unit A July 1981)). In spite of the recent enactment of ERISA, the court stated that Congress had not provided guidance in dealing with previously qualified trusts and granted summary judgment for the employee, citing Greenwald. Id. 
B. Woodson v. Commissioner.

In Woodson v. Commissioner 49 the Tax Court followed the Second Circuit's bifurcation approach. One judge filed a strong dissenting opinion, however, offering four reasons why the date of fund distribution, rather than the date of fund contribution, should be determinative of the distribution's tax treatment. First, the dissent looked at the language of the statute and found no support for bifurcating a trust into exempt and nonexempt portions. ${ }^{50}$ The dissent noted that section 402(a)(2) limits preferential tax treatment of lump-sum distributions to instances in which the distribution flows from an employee trust that is exempt under section 501(a). The dissent concluded that since all parties agreed that the distribution did not flow from an exempt trust, section 402(b), which provides for ordinary income treatment, should govern. ${ }^{51}$

Second, the dissent found nothing in the legislative history to support bifurcation. ${ }^{52}$ The dissent stated that none of the early Code revisions indicated that the trust's funds should be divided between exempt and nonexempt periods. Furtherinore, rules for preferential tax treatment for distributions from exeinpt trusts were provided before ERISA, revised in great detail as part of ERISA, and amended in later tax legislation. Therefore, if Congress intended to allow bifurcation, it had ample opportumity to so indicate. ${ }^{53}$ The dissent stated that through its continuing legislation, Congress had explored alternative sanctions inore sharply focused than blanket disqualification, ${ }^{54}$ but had retained disqualification as appropriate in certain instances of pension fund mismanagement. 55 The dissent argued that the inajority sought "to supply an alleged omission in the statute, on the basis of no examination of alternatives, no opportunity for public coinment, and no articulation of the method by which the time-allocation of assets is to be made."56

49. 73 T.C. 779, 784-86 (1980), rev'd, 651 F.2d 1094 (5th Cir. Unit A July 1981).

50. Id. at 787 (Chabot, J., dissenting).

51. Id.

52. Id. at 787-88.

53. Id. at 788.

54. Id. at $790 \mathrm{nn}$. 9-11. The Tax Reform Act of 1969 changed the penalties for certain violations by private foundations, replacing disqualification with an excise tax. Tax Reform Act of 1969, Pub. L. No. 91-172, § 101(b), 83 Stat. 498. In certain instances, the excise tax was imposed on the specific individual responsible for the violation. Id., 83 Stat. at 499-500. The Tax Reform Act of 1976 took similar action with respect to excess lobbying violations. Tax Reform Act of 1976, Pub. L. No. $94-455, \S 1307(b), 90$ Stat. 1722. ERISA replaced disqualification with taxation in a number of areas, including violations arising from excess contributions to "H.R. 10 plans," self-dealing, underfunding, and failure to meet minimum vesting standards. ERISA $\S 1012$, I.R.C. $\S \S 411,4971$, 4973(b), 4975(a) (1982).

55. Woodson, 73 T.C. at 789 (Chabot, J., dissenting).

56. Id. at 790 . 
Third, the dissent pointed out that in several of the cases the employee requesting bifurcated treatment had been the plan's decisionmaker and had been operating the pension plan for his own exclusive benefit. ${ }^{57}$ The dissent argued that the inajority holding could in effect make it more tempting for a company officer to use a trust for his own benefit, thereby undercutting legislation enacted to protect rank-and-file employees. 58

Finally, the dissent noted that calculating the amount of the distribution subject to favorable tax treatment would be difficult under the bifurcation approach. ${ }^{59}$ The bifurcation approach would allow einployer contributions to be divided into predisqualification and postdisqualification portions. But administrative difficulties would arise because a portion of the fund would be attributable to the earnings of both pre- and postdisqualification contributions, and the majority's method of bifurcation did not specify which tax treatment should apply to these earnings.

The dissent's concerns proved persuasive on appeal. Reversing the Tax Court's decision, ${ }^{60}$ the Fifth Circuit provided a number of reasons for rejecting the Greenwald approach. The court declared that the statutory language at issue was unambiguous and precluded bifurcation. ${ }^{61}$ The court also found it significant that Congress had extensively revised the Code's treatment of pension plans but had not altered 402(a)(1).62 The court concluded that if Congress wished to avoid a possible inequitable outcome, Congress itself, rather than the courts, should make the necessary modification. ${ }^{63}$ Finally, the court restated the administrative and enforcement concerns raised by the dissent below. ${ }^{64}$

The Fifth Circuit forwarded an additional argument against the bifurcation approach. The court concluded that Treasury Regulation section 1.402(a)-1(a)(1)(ii) ${ }^{65}$ provided the key to interpreting section 402(a) because the regulation clearly states that section 402(a) and its provision for preferential tax treatment relate only to a trust that is exempt for the taxable year in which the distribution is inade. ${ }^{66}$ Supported by a recent Supreme Court decision holding that courts should consider Treasury

57. Id. at $788-89$.

58. Id. at $789-90$.

59. Id. at 791. In the case of a deferred benefit plan, the accurate allocation of funds would become even more complex.

60. Woodson v. Commissioner, 651 F.2d 1094, $1095-96$ (5th Cir. Unit A July 1981).

61. Id. at 1095-96.

62. Id. at 1095 n.4.

63. Id. at 1096.

64. Id. at 1095 n.4.

65. This regulation has not been changed since Woodson. Compare Treas. Reg. $\$ 1.402(a)-$ 1(a)(1)(ii) (1966) with 26 C.F.R. $\S 1.402(a)-1(a)(1)(i i)$ (1986).

66. Woodson, 651 F.2d at 1096. 
regulations valid if they implement the congressional mandate in some reasonable fashion, ${ }^{67}$ the court determined that the Treasury regulation was valid and conclusive on the issue.

The Tax Court now found itself faced with a split in the circuits: the Second Circuit in Greenwald had held that the status of the trust at the time of contribution controlled the tax treatment of the later distribution, while the Fifth Circuit in Woodson had held that the trust's status at the time of distribution was controlling. The Tax Court is free to follow either line of reasoning ${ }^{68}$ and has consistently followed the Greenwald approach.69 In two cases, however, the Umited States Courts of Appeals for the Sixth ${ }^{70}$ and the Seventh ${ }^{71}$ Circuits have reversed the Tax

67. Rowan Cos. v. United States, 452 U.S. 247, 252 (1981).

68. The Tax Court is compelled to follow the precedent of a United States Court of Appeals only in cases appealable to that court. See Golsen v. Commissioner, 54 T.C. 742, 756-57 (1970), aff'd, 445 F.2d 985, 990 (10th Cir.), cert. denied, 404 U.S. 940 (1971).

69. See Woodson, 73 T.C. at 786; Sturdivant v. Commissioner, 39 T.C.M. (CCH) 1022, 1025 (1980); Baetens v. Commissioner, 82 T.C. 152, 155 (1984), rev'd, 777 F.2d 1160 (6th Cir. 1985); Benbow v. Commissioner, 82 T.C. 941,947 (1984), rev'd, 774 F.2d 740 (7th Cir. 1985); Boggs v. Commissioner, 83 T.C. 132, 152-53 (1984), vacated on other grounds, 784 F.2d 1166 (4th Cir. 1986).

70. Baetens v. Commissioner, 777 F.2d 1160 (6th Cir. 1985). In Baetens, an employee and shareholder received a lump-sum distribution from the profit-sharing trust in 1977. He rolled over the entire amount into an IRA. The distribution was attributable to employer contributions prior to 1974. In 1979, the IRS retroactively revoked the trust's exempt status as of March 31,1974. Id. at 1161. The distribution was therefore composed entirely of contributions made while the pension was exempt.

The Tax Court followed the reasoning it had outlined three years earlier in Woodson and concluded that the employee's entire distribution would be accorded favorable tax treatment. Baetens v. Commissioner, 82 T.C. 152, 170 (1984).

On appeal, the Sixth Circuit characterized the case as a "classic conflict of equity and statutory intent." In a detailed opinion, the court refuted the Tax Court's supposition that the history of recent legislation on the issue was overwhelmingly pro-employee. Although it recognized that an important goal of Congress was the protection of pension funds, the court noted that Congress was equally concerned with regulating the pension fund area. Baetens, 777 F.2d at 1164-66. The court found the language of the statutes unambiguous, and concluded that "the statute allows special tax treatment under section $402(\mathrm{a})(5)$ only to plan participants who receive distributions from plans and trusts qualified at the time of the distribution." Id. at 1167.

71. Benbow v. Commissioner, 774 F.2d 740, 744-46 (7th Cir. 1985). The Tax Court had adhered to its reasoning in Woodson and Baetens and allowed tax-free rollover into an IRA of that portion of the distribution allocable to contributions made prior to the retroactive date of disqualification. Benbow v. Commissioner, 82 T.C. $941,947-48$ (1984). The nonqualified portion of the rollover was subject to the excise tax under 26 U.S.C. $\$ 4973$ (1982). Benbow, 82 T.C. at 948.

Echoing the conclusion of the Fifth Circuit in Woodson, the Seventh Circuit held that the language of the statutes and the Treasury regulation required denial of tax benefits, and that any division of the trust into qualified and nonqualified components would be improper. Benbow, 774 F.2d at 744-45. Although the results seemed somewhat harsh, the Seventh Circuit held that the statute must be enforced as written by Congress. Id. at 745 .

The Fourth Circuit was recently presented a case involving the same issue. See Boggs v. Commissioner, 784 F.2d 1166 (4th Cir. 1986). The Tax Court held that an employee was eligible to rollover that portion of the distribution allocable to contributions made before the date of retroactive disqualification. Boggs v. Commissioner, 83 T.C. 132, 151-52 (1986). The Fourth Circuit reversed 
Court, rejecting the Greenwald approach and adopting the Fifth Circuit's approach.

\section{Statutory ANALysis, Legislative Scheme, AND Equitable CONSIDERATIONS}

Given the conflict ainong the circuits regarding the correct application of sections 402(a) and 402(b), a close examination of the Code sections, the legislative scheine, and relevant equitable considerations is indicated. Whether the tax treatment of the lump-sum payinent should be tied to the date of fund contribution or distribution could be elucidated by one or more of these factors.

\section{A. Sections 402(a) and 402(b) Are Not Ambiguous.}

The Code sections that deal with the taxation of lump-sum distributions take a year-by-year approach in determining whether a pension plan is qualified or nonqualified and outline the appropriate tax treatment in either case. Section 402(a) stipulates preferential tax treatment of a distribution "which is exempt from tax under section 501(a)."72 This phrase is repeated in the provision discussing capital gains treatment for funds contributed before January 1, 1974 (section 402(a)(2)), in the provision describing eligibility for rollover (section 402(a)(5)(D)(i)(II), which refers to subsection (e)(4)(A)), and in the provision defiming a qualified lump-sum distribution (section 402(e)(4)(A)). Section 402(b) stipulates ordimary income treatment for any distribution for any trust "not exeinpt from tax under section 501(a)."73

At issue is the precise meaning of "is exeinpt." The Second Circuit interpreted the clause to mean exempt at the time of contribution. ${ }^{74}$ The Fifth, Sixth, and Seventh Circuits have strongly stated that the phrase inust mean exempt at the time of distribution. ${ }^{75}$ Each interpretation is plausible on its face. The "exempt at time of contribution" interpretation appears to be bolstered by the year-by-year approach in section $402(\mathrm{~b})$ for determining exempt status. But the year-by-year approach is more logically applied in the case of a nonexempt trust that becoines exempt,

the Tax Court's decision on the basis of a different issue-that the commissioner had abused his discretion in applying the disqualification retroactively-and did not reach the issue of how the distribution would be taxed. Boggs, 784 F.2d at 1169-70.

72. I.R.C. $\S 402(\mathrm{a})(1)(1982)$.

73. I.R.C. $\S 402$ (b) (1982).

74. Greenwald v. Commissioner, 366 F.2d 538, 541 (2d Cir. 1966).

75. Baetens v. Commissioner, 777 F.2d 1160, 1166 (6th Cir. 1985); Benbow v. Commissioner, 774 F.2d 740, 744 (7th Cir. 1985); Woodson v. Commissioner, 651 F.2d 1094, 1095 (5th Cir. Unit A July 1981). 
because it remedies the double taxation that would otherwise occur. ${ }^{76}$

Futhermore, Treasury Regulation section 402(b)-1(c)(1) eliminates any ambiguity in section 402(a), and strongly supports the interpretation embraced by the Fifth, Sixth, and Seventh Circuits. The regulation links the taxation of the distribution to exemption under section 501(a) for the taxable year in which the distribution is inade.77 Thus, section 402(a) is not ambiguous and the status of the trust at the time of distribution, rather than at the time of contribution, should be determinative of the tax treatment of the lump-sum distribution.

\section{B. The Legislative Scheme.}

The comprehensive legislative scheine regarding pension plans and Congress's failure to amend section 402(a) provide support for rejecting the bifurcation approach. Congress wanted to encourage the growth of both pension plans and retirement savings by the private sector. ${ }^{78}$ However, Congress was also extremely concerned with the abuses it saw in its survey of private pension plans, and attempted to remedy these abuses

76. The employee would otherwise be taxed once under section 402(b) when the contributions were made and again under section 402(a) at the time of distribution.

77. Treas. Reg. $\$ 1.402$ (b)-1(c)(1) (1978).

78. Congressional debate prior to the enactment of ERISA demonstrates Congress's desire to encourage pension saving. H.R. REP. No. 533, 93d Cong., 2d Sess. 5, reprinted in 1974 U.S. CODE CONG. \& ADMIN. NEWS 4639, 4643. In particular, Congress intended that the employee's right to the pension funds be protected through increased vesting proportionate with length of service. The report stated: "[i]n its final analysis, the issue basically resolves itself into whether workers, after many years of labor, whose jobs terminate voluntarily or otherwise, should be denied benefits that have been placed for them in a fund for retirement purposes." H.R. REP. No. 533, 93d Cong., 2d Sess. 6, reprinted in 1974 U.S. CODE CONG. \& ADMIN. News 4639, 4644-45. Congress also wanted to ensure portability-the ability to transfer vested funds from one exempt pension fund to another. H.R. REP. No. 1280, 93d Cong., 2d Sess. 341, reprinted in 1974 U.S. CODE CONG. \& ADMIN. NEwS 5038,5121 . This goal was particularly evident in the Senate's proposal to establisli a central portability fund, whicl was to serve as a conduit for transfer of pension dollars when the employec changed jobs. S. REP. No. 383, 93d Cong., 1st Sess. 74-78, reprinted in 1974 U.S. CoDE CoNG. \& ADMIN. NEwS 4890, 4958-62.

Although Congress eventually replaced the central portability fund witl the IRA, the Senate's discussion of the proposed fund is enlightening because it evinces an intent that tax treatment should stem from the trust's status at the time of the distribution:

The central fund may receive transfers only from employee benefit plans (or from einploy. ees receiving final distributions from these plans) that are qualified under the Internal Revenue Code. If the fund receives notice from the Secretary of the Treasury that a final determination las been made that a plan was not qualified at the time that a transfer was made to the fund, the balance of eacl participant's account attributable to transfers from that plan (in the year the plan is not qualified) will be paid from the fund to the participant. The amount paid is to be included in the participant's income in the year it is paid to the participant. This generally follows present law, since plan participants currently are taxed as receiving ordinary income when they receive transfers from plans whicl are not qualified in the year of distribution.

S. REP. No. 383, 93d Cong., 1st Sess. 75, reprinted in 1974 U.S. CODE CONG. \& ADMIN. News $4890,4959$. 
through comprehensive regulation and standardization of the plans. ${ }^{79}$ Although it was not unmindful of the harsh effects that attend loss of exempt status, Congress retained disqualification as an appropriate sanc$\operatorname{tion}^{80}$ for failure to meet minimum standards. ${ }^{81}$ Recognizing that disqualification would impose a hardship on employees, Congress provided excise tax penalties as sanctions for certain prohibited transactions in the management of trusts in order that abuses could be cured without disqualification. ${ }^{82}$ Because the study of private pension planning was thorough, and the resulting ERISA legislation detailed, Congress must be viewed as having spoken decisively on the standards and sanctions it wished to establisli.

In addition, Congress has continued to fine-tune the Code provisions dealing with einployee pension plans since the enactment of ERISA. Congress has made many recent major amendments to the Code, including the Tax Equity and Fiscal Responsibility Act of 1982, the Deficit

79. See H.R. REP. No. 533, 93d Cong., 2d Sess. 9-10, reprinted in 1974 U.S. CodE CoNG. \& ADMIN. NEws 4639, 4647-48. This report stated:

Underlying the provisions of this Act is a recognition of the necessity for a comprehensive legislative program dealing not only with malfeasance and maladministration in the plans, or the consequences of lack of adequate vesting, but also with the broad spectrum of questions such as adequacy of funding, plant shut downs and plan terminations, adequate communication to participants, and, in short, the establishment of certain minimum standards to which all private pension plans must conform if the private pension promise is to become real rather than illusory.

Id.

80. See S. ReP. No. 383, 93d Cong., 2d Sess. 94-95, reprinted in 1974 U.S. Code Cong. \& ADMIN. News 4890, 4978. This report stated:

Under present law, a trust forming part of a qualified retirement plan loses its exemption from taxation if it engages in a prohibited transaction. With loss of exemption, special tax benefits relating to qualified plans also may be denied, including deferral of taxation by employees and loss of deductions by employers contributing to the trust. In practice these sanctions have not been satisfactory in discouraging prohibited transactions. . . .

In addition, the present law's sanctions for engaging in prohibited transactions tend to fall upon innocent einployees. For example, if a trust is disqualified because of an act of the trustee and the employer, the income tax imposed upon a disqualified plan may be paid out of funds otherwise available to provide employees' retirement benefits. Furthermore, because of the prohibited act of an employer and trustee, an employee may have to pay tax on contributions made on his behalf before he actually receives the amounts attributable to the contributions. This possible loss to innocent employees has caused the Service to be reluctant to impose the sanctions.

To resolve these problems, the committee bill changes the method of enforcing the prohibited transaction rules. It imposes sanctions for prohibited transactions upon the parties in interest and fiduciaries who engage in these transactions in place of the sanctions now imposed on the employee benefit trusts.

Id.

81. See S. REP. No. 383, 93d Cong., 2d Sess. 94-95, reprinted in 1974 U.S. CoDE CoNG. \& ADMIN. NEWS 4890, 4978.

82. See supra note 54 and accompanying text. In a recent case, the Tax Court held that the excise tax penalty provisions of ERISA do not preclude the IRS from disqualifying a plan if there is evidence of a pattern of prohibited transactions. Winger's Dep't Store, Inc. v. Commissioner, 82 T.C. 869,887 (1984). 
Reduction Act of 1984, and the Tax Reform Act of $1986 .{ }^{83}$ Congress has had ample opportunity to review section 402(a) and clarify any perceived ambiguities. Yet Congress has never advocated bifurcation of trusts into exempt and nonexempt portions or bifurcation of lump-sum distributions into portions qualifying for preferential tax treatment and portions to be taxed as ordinary income.

\section{Inapplicability of Equitable Considerations.}

The Fifth, Sixth, and Seventh Circuits have stated forthrightly that equitable considerations inust be ignored in interpreting a clearly worded tax statute. ${ }^{84}$ The Second Circuit and the Tax Court, however, have been moved by consideration of three equitable arguments im support of the bifurcation approach. ${ }^{85}$ First, the bifurcation approach is said to lessen the harsh result of demal of preferential tax benefits for the employee who did not participate in or contribute to the fund mismanagement. Second, the bifurcation approach is said to prevent inequitable treatment between two participants of the same disqualified plan who contributed funds during an identical time span, but who received the distribution at different times-one just prior to, and the other just after disqualification. Third, it is said to preclude the extension of the reach of the disqualification to a date long before the event that triggered the disqualification.

The denial of preferential tax treatment for distributions made after the date of disqualification will unquestionably have inequitable effects. First, the effects of disqualification are devastating to the employee, ${ }^{86}$ in terms of both the immediate taxes owed and the probable reduction in the standard of living during retirement. This result seems especially harsh when that employee is an innocent party; the employee will be penalized even though he had no input in the decisions made by trust management. ${ }^{87}$ In part to avoid the harshness of total disqualification of the distribution, the Second Circuit and the Tax Court have adopted the bifurcation approach.

Not only does "all or nothing" disqualification create a harsh result, but the penalty of disqualification and the resulting loss of tax benefits fall unevenly among employees in the same plan. An employee who re-

83. See supra note 14 and accompanying text.

84. See Baetens v. Commissioner, 777 F.2d 1160, 1164, 1167 (6th Cir. 1985); Benbow v. Commissioner, 774 F.2d 740, 744 (7th Cir. 1985); Woodson v. Commissioner, 651 F.2d 1094, 1095-96 \& n.4 (5th Cir. Unit A July 1981).

85. See Greenwald v. Commissiouer, 366 F.2d 538, 541 (2d Cir. 1966); Baetens v. Commis siouer, 82 T.C. 152, 167 (1984), rev'd, 777 F.2d 1160 (6th Cir. 1985); Woodson v. Commissioner, 73 T.C. 779, 784 (1980), rev'd, 651 F.2d 1094 (5th Cir. Unit A July 1981).

86. See supra note 30 and accompauying text.

87. See Woodson, 73 T.C. at 784. 
ceives a distribution prior to the an IRS determination of disqualification retains all the tax benefits promised at the time of contribution. The employee who retires after the retroactive adverse determination loses favorable tax treatment not only for contributions made after disqualification, but also for those contributions made before disqualification. It is precisely this inequitable treatment of meinbers of the same plan that the Second Circuit sought to avoid when it adopted the bifurcation approach in Greenwald.

The third inequity linked to the complete disqualification of a lumpsum distribution results from the retroactive nature of an IRS disquahification. The Commissioner is granted the power to apply an adverse determination retroactively, unless such retroactive application would amount to a clear abuse of discretion. ${ }^{88}$ Under the Greenwald approach, the effects of retroactive disqualification reach back to the date of the event that triggered disqualification; the denial of tax benefits is therefore retroactive to the point of mismanagement. But when the courts follow the Woodson approach, the disqualification reaches even farther back in time, to the point when the funds were contributed. Preferential tax treatment is lost not from the date of adjudication or the date when the mismanagement occurred, but from the date when the contribution was made. The retroactive reach of an IRS disqualification in effect predates any mismanagement or prohibited activity. The result to the employee is the same as if the trust had been disqualified from the date of the first contribution. This result obtams notwithstanding the employee's good faith reliance on the tax-exempt nature of the trust and the benefits that would accrue at retirement.

The Fifth, Sixth, and Seventh Circuits recognized the unfair effect of their decisions on the individual employee. ${ }^{89}$ These courts, however, were more concerned with the broader class of pension participants; they believed that adopting the bifurcated approach would encourage abuse by pension fund fiduciaries. Under the bifurcated approach, a decisioninaker/plan participant can enhance his own fortune with little risk of substantial loss of tax benefits since he can withdraw most of his account from the plan as a tax-favored lump-sum distribution should he happen to get caught. ${ }^{90}$

88. See supra note 29 and accompanying text.

89. See Baetens v. Commissioner, 777 F.2d 1160, 1164 (6th Cir. 1985); Benbow v. Commissioner, 774 F.2d 740, 744 (7th Cir. 1985); Woodson v. Commissioner, 651 F.2d 1094, 1095 (5th Cir. Unit A July 1981).

90. See Woodson v. Commissioner, 73 T.C. 779, 789 (1980) (Chabot, J. dissenting), rev'd, 651 F.2d 1094 (5th Cir. Unit A July 1981). Indeed, several of the employees involved in suits on this issue have been in the position of the decisionmaker. Greenwald and Woodson both were fiduciaries of the trust funds later retroactively disqualified. See Greenwald v. Commissioner, 366 F.2d 538, 
This trade-off of an inequity to an individual for the protection of a greater class of participants occurs in a related area of the law: tax treatinent of charitable organizations. Organizations qualifying as tax-exeinpt under section 501(c)(3) also are closely inonitored by the IRS and periodically audited. If such an organization engages in a prohibited activity, such as lobbying, ${ }^{91}$ that organization will be disqualified and will lose its tax exempt status. Both third parties contributing to that organization and the final beneficiary of funds contributed to the organization will be prejudiced as a result of disquahification. Those parties who have contributed to the organization will lose the tax deduction their contribution would have triggered, and the final beneficiary of the charitable organization (such as an art museum) will be hurt by the resulting loss of contributions. Nonetheless, the disqualification is inade because it ensures greater fairness in the enforcement of ninimum standards for charitable organizations as a whole. The entire nonprofit sector is protected as a result. 92

The same idea of protecting the broader good, even when one result is hardship to the individual, applies to pension fund taxation. Although balancing the equities in this pension tax arena is difficult, the individual employee is best protected by the policy that most strongly deters abuse of the fund by the employer. With pension funds, as with charitable organizations, the strongest deterrent is disqualification. Courts should not be so overconie with sympathy for the individual employee that they ignore the legislative directive to protect the broader class of pension participants.

\section{CONCLUSION}

The Greenwald interpretation has no support within the Code. The unambiguous language characterizes a trust fund as either exentpt or nonexempt. Treasury Regulation section 1.402(a)(1)(ii) reinforces this meaning by limiting favored tax treatment to a trust that is exempt for the taxable year in which the distribution is made. The Fifth, Sixth, and Seventh Circuits are justified in stating that Congress clearly intended an

539-40 (2d Cir. 1966); Woodson, 73 T.C. at 780 . Evidence of discriminatory management by the employee was also apparent in Epstein v. Commissioner, 70 T.C. 439, $443-44$ (1978).

91. I.R.C. § 501(c)(3) (1982). See generally, Gallagher \& Jarchow, How to Organize and Meet the Tax Requirements of Public Charities and Private Foundations, 8 TAX'N FOR LAw. 302 (1980); Temple \& Gorbaty, How to Properly Obtain and Maintain Tax-Exempt Status for a Charitable Organization, 14 TAX'N FOR LAW. 16 (1985).

92. But a difference can exist between the employee's interest in the pension fund and a third party's interest in a charitable fund. The employee's interest in the pension fund becomes a vested one, i.e., a legally recognized fixed right to future enjoyment of his portion of the trust. The beneficiary of a charitable trust has no such vested interest. 
all-or-nothing interpretation. None of the congressional reports surrounding the enactment of ERISA support the bifurcation approach. And despite almost yearly amendments to the Code-including three inajor revisions, the last in 1986-no changes have been made in the language of 402(a) or (b). Congress has had many opportunities to indicate that an intent to allow bifurcation, yet it has failed to do so.

The bifurcation approach gives rise to the problem of defining what portion of the fund is predisqualification and what portion of the fund is postdisqualification. It is difficult enough to trace back annual contributions; it is even more difficult to apportion the earnings attributable to those contributions. When faced with a defined benefit plan (where the einployer does not provide a fixed formula for making contributions, but rather a predetermined final benefit), accurate allocation of funds would becoine even more complex.

Congress did not intend this complex bifurcation of a single trust. Rather, it has retained disqualification as the best deterrent of fund mismanagement. The courts must recognize their responsibility to follow the legislative directive set out in the Code. Sections 402(a) and (b) should be given their literal interpretation. The courts must look beyond the inequities worked in individual cases and give full effect to congressional intent. Congress, not the courts, must alleviate the perceived harshness of section 402 . 